\title{
SUSTAINABLE CONCEPT FOR BORDER SETTLEMENT AT KAMPUNG ROMO KALISARI SURABAYA
}

\author{
Satya W. Santosa*, Chintia P. Agnesi*, Ricca A. Alamsyah** \\ *Freelance architect, Surabaya \\ ***Freelance architect, Kendari \\ e-mail: satyasantosa@yahoo.com
}

\begin{abstract}
The development of a city tend only to pay attention to the downtown area than in the border area. It can also be seen in the city of Surabaya, particularly in Subdistrict Romo Kalisari which is a border kampung between Surabaya and Gresik. Border area is the main access from out of Surabaya to go to other cities and shows the identity of towns, especially to give a first impression on the city. But in Kampung Romo Kalisari, it has not been seen any effort to improve the quality of people.

According to the theory used in this study, one of the things that are important in the development of the sustainable city is the economic improvement, particularly on the city's infrastructure. Border area also needs a management that supports the development of sustainable cities. Therefore, this study will provide concrete solutions on improving the city's infrastructure, such as transport and education facilities as well as the trade, which can be applied in the development of border kampungs in the Kampung Romo Kalisari, Surabaya.
\end{abstract}

Keywords: border settlement, sustainable, Kampung Romo Kalisari, infrastructure

\begin{abstract}
ABSTRAK
Pembangunan kota cenderung hanya memerhatikan pada kawasan pusat kota daripada kawasan perbatasan. Hal ini juga dapat diamati di Surabaya, khususnya di Kelurahan Romo Kalisari yang merupakan kampung perbatasan antara Surabaya dan Gresik. Kawasan perbatasan merupakan akses utama dari bagian luar Surabaya untuk menuju kota lain sekaligus menunjukkan identitas kota, terutama untuk memberikan kesan pertama terhadap kota tersebut. Namun di Kampung Romo Kalisari, tidak terlihat adanya usaha untuk meningkatkan kualitas manusianya.

Berdasarkan teori yang digunakan dalam penelitian ini, salah satu hal yang penting dalam pembangunan kota berkelanjutan adalah peningkatan ekonomi, khususnya dalam hal infrastruktur kota. Kawasan perbatasan juga membutuhkan pengelolaan yang mendukung pembangunan kota berkelanjutan. Dengan demikian, penelitian ini akan memberikan solusi konkrit dalam meningkatkan infrastruktur kota, seperti
\end{abstract}


fasilitas transportasi dan pendidikan selain fasilitas perdaganganm yang dapat diterapkan pada pembangunan kampung perbatasan di Kampung Romo Kalisari, Surabaya.

Kata kunci: permukiman perbatasan, berkelanjutan, Kampung Romo Kalisari, infrastruktur

\section{INTRODUCTION}

\section{Border Area, Infrastructure, and Sustainable Development}

Settlement in the border area should be considered in a city. The definition of the border area is a region that is located at the city fringe, directly adjacent to the next region. Within the scope of the country, the border area management paradigm in the past as a "backyard" of the country (Indonesia) carries implications for the current condition of the border area that are isolated and left behind in social and economic terms (Abdul, 2012). It also occurs on the border between cities in Indonesia. Economic activities and infrastructure are less a concern for the government, especially municipalities concerned.

City infrastructure, such as transport and education facilities, are the main facilities needed by people living in the border areas. Society tends to cross the border to get education and do economic activities because of the location that is closer than in their own city.

Surabaya City has developed some of the border area as if the barriers between Surabaya with other regions does not exist. It is beneficial in terms of sustainable development, for example, at the boundary between the regency of Sidoarjo and Surabaya in district of Waru. However, sustainable development does not developed properly. There are some border areas less noticed by the municipality of Surabaya. These areas are similar compared to the development of kampung in the centre of the city of Surabaya.

One of the border areas that in this research is used is Kampung Romo Kalisari. The kampung is located in the Romo Kalisari Sub-district, Benowo District, Surabaya. The kampung is directly adjacent to the regency of Gresik, separated by a river and Kampung Osowilangun, Surabaya (Figure 1).

This kampung has the same problems as other border areas. Lack of infrastructure is a major issue raised in the kampung Romo Kalisari. Residents of Kampung Romo Kalisaro more often do shopping in Gresik than in Surabaya. The same is true for education. Kampung Romo Kalisari is still the responsibility of the city government of Surabaya.

In addition, Kampung Romo Kalisari is one of kampung inhabited by fishermen. But the number of fishermen in the kampung tend not to continue into the next generation. It can also have an impact on economic activity of these kampung. 


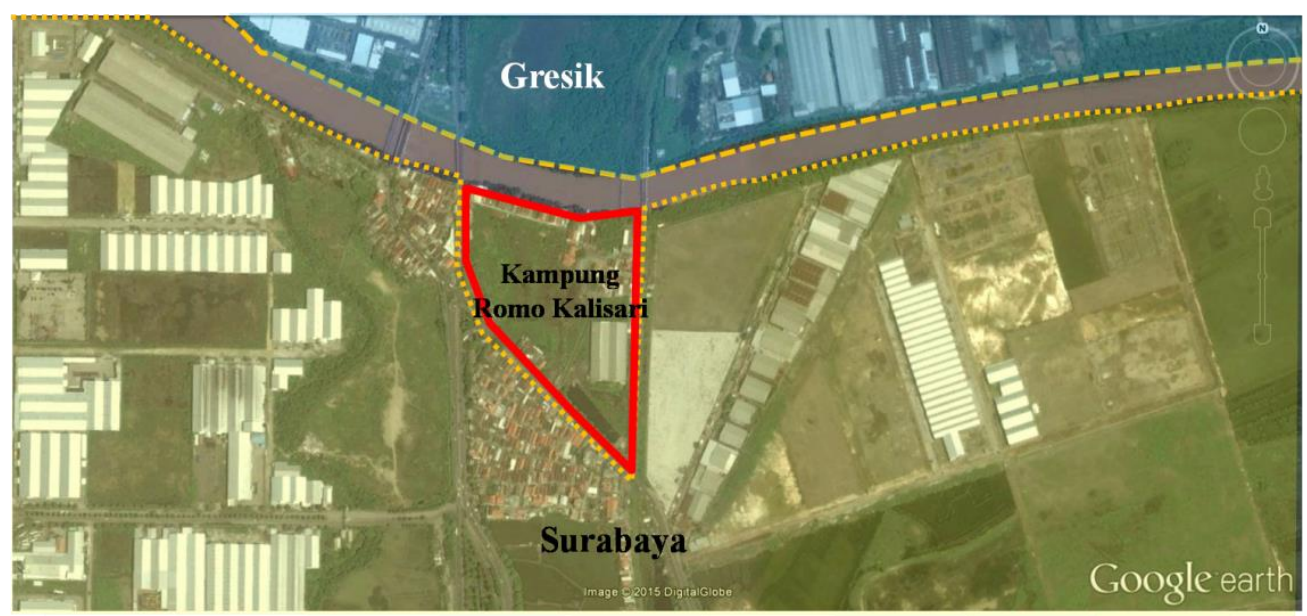

Figure 1. Map showing Kampung Romo Kalisari Source: Google Earth image

Therefore, this study would emphasize the sustainable development of kampung development or sustainable in the border area through the theory of sustainable development and come out with solution that can help the development in Kampung Romo Kalisari.

According to Walter (1992), to develop a sustainable development, seven principles need to be applied to a region. In the study, the principles of sustainable development will be applied to Kampung Romo Kalisari emphasising the development of local agriculture and local businesses, products, and services; advanced transportation, communication and product system; and support broad based education for participatory governance.

\section{Objectives}

This study aims to provide solutions to the city government in caring for the development of border areas in forming the images of the city and also maintaining the sustainability of development in the border areas, especially in Kampung Romo Kalisari, Surabaya.

\section{THEORY / RESEARCH METHODS}

\section{Housing and Settlement}

According to Yodohusodo (1991), Housing can be interpreted as the manifetation of human self, either individually or in a unity, togetherness with the natural environment and may also reflect the standard of living, personality, prosperity, and civilization of the human inhabitants of the community or a nation. Referring to Juhara (2000:31), housing cannot be viewed simply as an inanimate object or a mere means of live, but more than that, housing is a living process, the 
presence of humans in creating a living space in the community and natural surroundings.

More than 60 percent of the city consists of the settlements, whether it is good or in por condition, it does not directly reflect the success of a city. Referring to Sinulingga (1999) in his book Urban Development: Overview of Regional and Local, good neighborhoods should meet the following criteria:

1. Having access to service centres such as education, health, commercce. Access is achieved by making roads and means of transport in such that settlements and housing has access individually by local roads, and transportation terminals in the settlement.

2. Equipped with facilities such as a playground for children, field or park, place of worship, education, health and serviced by electricity and telephone networks.

3. Has drainage facilities, rain water can drain quickly and would not cause puddles despite heavy rains.

4. Has water supply facility, a distribution network that is ready to reach each home

5. Equipped with sewage/ faeces disposal that can be made with individual systems and septic tank seepage field, or communal septic tank.

6. The settlement must be served by a waste disposal facility on a regular basis in order to remain as comfortable residential environment.

Based on the explanation above, the infrastructure system becomes an important point in the service to the community to support the improvement of quality of life and economic development. Availability of infrastructure greatly affect the standard quality of life, especially in education and health. The accessibility of public facilities for the community such as schools, market, open green space, and other service centres are very important to meet the competitive world and should be noted by the municipal government.

\section{City's Border Area Development}

Developments in border areas that are not integrated due to differences in interests of integrated planning and authority resulting in the growth of housing and settlements that is unplanned and uncontrolled, can eventually lead to problems such as land use conflicts, inefficient urban infrastructure services, environmental pollution result in environmental degradation in overall (Siregar, Ismail, and Nasution, 2010).

The border areas of the city is a gateway of the city that should be in proper physical condition, facilities, and infrastructure more attention. The quality of people and the environment in the border area should not much different to downtown area.

\section{Sustainable Development}

Sustainable development is a synergy between social, economic, and environmental appears where all three have to exist in balance. Principle of sustainable development on meeting the needs of the present without compromising the needs of 
the future generations. Referring to Walter (1992), the concept of sustainable development is divided into seven issues, namely:

1. Establish true cost pricing as the basic of economic viability.

2. Support local agriculture and local business, product, and services.

3. Develop cluster, mixed-use, pedestrian oriented, ecological communities.

4. Utilize advanced transportation, communication, and product system.

5. maximize conservation and develop renewable resources.

6. Establish recycling program and recycled material industries.

7. Support broad based education for participatory governance.

\section{Methods}

Analyses of case studies are conducted with field observaton and interviews with a number of residents in the fishermen Kampung Romo Kalisari located at the border between the city of Surabaya and Gresik. This interview was conducted to identify the condition of the fishermen kampung on the border and identifying the existing problems in the settlement. Secondary data obtained from the field associated with the concept of sustainable development theory (Walter, 1992).

\section{RESULTS AND DISCUSSION}

The study will focus on the design of sustainable settlement to the kampung that are in the border area. The discussion can be a solution for Kampung Romo Kalisari. Here are some of the infrastructure needs to be improved:

1. Means of education for the kampung inhabitants.

The problem found is the lack of infrastructure support for the activities of residents of Kampung Romo Kalisari. Education facilities is less valued because after the primary level, the people in Romo Kalisari should proceed to junior and senior high school where the school location nearest to Romo Kalisari Surabaya is still far and not in one area. So that many people from Romo Kalisari attend schools in Gresik.

2. Facilities for the livelihood of the fishermen in particular

Kampung Romo Kalisari actually has the potential to become a developed fishing kampung, given the strategic location of this kampung to the border area of marketing for Surabaya and Gresik. Lack of facilities to sell seafood from the fishermen in the kampung is also a constraint in infrastructure.

3. Waste disposal facilities in the kampung

Condition of Kampung Romo Kalisari has no area for was collection station to be taken to a landfill. In the swampland at the edge Kampung Romo Kalisari there are piles of garbage and certainly will stimulate disease to people in this kampung.

A settlement must be supported by good infrastructure, but Kampung Romo Kalisari still has minimal infrastructure and should be developed in order to be a livable and sustainable settlement. From the analyses, a few result on the 
infrastructure of this kampung are poor and in need of repair and upgrading. From this, it can be concluded that this kampung has some problems related to the development of education and economics.

\section{CONCLUSIONS}

Kampung Romo Kalisari has the potential to be developed into a good sustainable kampung, and the western border areas Surabaya is not well developed as the southern border of Surabaya. The kampung has the potential to be developed into a better fishermen kampung.

But the problem of infrastructure is a barrier to the development of this kampung. The concept and reference to the solution of this study, and already discussed to the existing problems. It should further note:

1. Means of education for inhabitants in Kampung Romo Kalisari

For a residential educational facilities should be equipped with educational facilities that meet the needs of residents, at least until high school, so the children of this kampung have easy access to knowledge and education.

2. Facilities for livelihood of fishermen in particular

For the fishermen in the kampung could be assisted to enhance maritime production, help could be assisted to enhance maritime production, help could be the motor boats, nets, and other equipment. From the production could boost the economy of Romo Kalisari residents, and improve the development of the kampung to be more advanced.

4. Waste disposal facilities

Waste disposal facilities in the kampung should be improved by providing a special area for the temporary dump which can then be directly transferred into landfills located in Benowo.

The solutions above are expected to improve the quality of life and education of people in Kampung Romo Kalisari, increase production and marketing of seafood from the fishermen, and the temporary bins located in the kampung is expected to maintain the cleanliness of the kampung environment and improve the existing mangrove ecosystem in Kampung Romo Kalisari. Waste can also be reprocessed into crafts that can be sold and boost the economy of the inhabitants of Kampung Romo Kalisari.

\section{REFERENCES}

Abdul, Andrea. (2012), Strategi Pengelolaan Kawasan Perbatasan, <http://hankam.kompasiana.com/2012/07/03/strategi-pengelolaan-kawasanperbatasan-474306.html> (Accessed on 28 December 2012).

Sanulingga, Budi. (1999), Pembangunan Kota: Tinjauan Regional dan Lokal. PT Penebar Swadaya, Jakarta.

Siregar, S., Ismail, A.M., Nasution, A.D. (2010), Kajian Preferensi Bermukim di Daerah Perbatasan Kota. Studi Kasus: Kelurahan Gedung Johor Kecamatan 
Medan Johor Kota Medan dan Desa Delitua Kecamatan Namorambe Kabupaten Deliserdang, 1(1), 1-7, Jurnal Arsitektur dan Perkotaan KORIDOR, Medan.

Walter, B., Arkin, L., Crenshaw, R. (1992), Sustainable Cities: Concept and Strategies for Eco-city Development, Eco-Home Media, Los Angeles.

Yudhohusodo, Siswono. (1991), Rumah untuk Seluruh Rakyat, Yayasan Padamu Negeri, Jakarta. 
This page intentionally left blank 